\title{
THE GOVERNMENT'S LIABILITY FOR THE USE OF PATENTED INVENTIONS.
}

The abstract right of the holder of letters patent from the United States, whether as original inventor or as assigriee, to receive compensation for the use of the paterited invention by the government itself, is thoroughly established. "The government cannot, after the patent is issued, make use of the improvement any more than a private individual, without license of the inventor or making compensation to him." "Agents of the public have no more right to take such property than other individuals under that provision ['the exclusive right to make, use, and vend, ' $R$. S., Section 4884 ], as it contains no exception warranting any such invasion of the private rights of individuals." "That the government of the United States, when it grants letters patent for a new invention or discovery in the arts, confers upon the patentee exclusive property in the patented invention which cannot be appropriated or used by the government itself, - without just compensation, any more than it can appropriate or use without compensation land which has been patented to a private purchaser, we have no doubt. The constitution gives to Congress power 'to promote the progress of science and useful arts by securing for limited times to authors and inventors the exclusive right to their respective writings and discoveries,' which could not be effected if the government had a reserved right to publish such writings or to use such inventions without the consent of the owner. Many inventions relate to subjects which can only be properly used by the government, such as explosive shells, rams, and submarine batteries to be attached to armed vessels. If it could use such inventions without compensation, the inventors could get no return at all for their discoveries and experiments. It has been the general practice, when inveritions have been

United States v. Burns, 12 Wall. 246 (1871).

- Cammeyer v. Newton, 94 U.S. 225,235 (1876). 
made which are desirable for government use, either for the government to purchase them from the inventors, and use them as secrets of the proper department; or, if a patent is granted, to pay the patentee a fair compensation for their use. The United States has no such prerogative as that which is claimed by the sovereigns of England, by which it can reserve to itself, either expressly or by implication, a superior dominion and use in that which it grants by letters patent to those who entitle themselves to such grants. The government of the United States, as well as the citizen, is subject to the constitution, and when it grants a patent the grantee is entitled to it as a matter of right, and does not receive it, as was originally supposed to be the case in England, as a matter of grace and favor."'

Such are a few of the expressions of the views of the Supreme Court on this subject, but clear and satisfactory as the law is in regard to the existence of a right, it is far from being equally so in regard to the practical enforcement of that right. The Court of Claims; though established in 185.5 , did not exist as a court in the proper sense of the term, with power to render a final judgment, until $\mathrm{I} 863$, or, strictly speaking, until $\mathrm{I} 866$, and it has always been a court of limited jurisdiction. As reorganized in 1863, its jurisdiction extended, inter alia, to "all claims founded upon any law of Congress, or upon any regulation of an executive department, or upon any contract, expressed or implied, with the government of the United States, and all claims which may be referred to it by either House of Congress." This provision granted no jurisdiction over wrongs done to individuals by the officers of the government acting in the belief that it was for its interest. Such matters were held to be reserved by Congress for its own determination." Hence there

Jones v. Campbell, ro4 U. S. 356 (288r).

- Gibbons v. United Slales, 8 Wall. 269 (1868), 275 ; Morgan v. United States, $x_{4}$ Wall. 531 (187r). In the first of these cases Mr. Justice Miller said: "Congress has wisely reserved the matter for its own determination." The wisdom will not be conceded by those who believe that the government should never be put in the position of granting compensation as a matter of special personal favor; that if 
could be no jurisdiction over infringements of patents, but the right of suit was clear enough in cases of express contract, as where payment of the stipulated royalty had been stopped under an erroncous idea that the contract was in conflict with a provision of the army regulations." The only instances of jurisdiction in cases of plain infringement, where no contract could be implied, have arisen under a special act or resolution of Congress." Where the officers of the government have wished to make an express contract, but have been unable to come to terms with the patentee and have gone on to use the patented device, recovery may be had, under an implied contract, the court fixing such rate of royalty as the evidence may show to be reasonable." Such a case would seem clearly to involve the exercise of the right of eminent domain, where the law implies a promise of compensation, upon which an action. would lie, within the jurisdiction of the Court of Claims, just as in cases of the taking of real estate; and where contractual relations between the parties have once been established by a judgment in such a case, the use of a device which the government avers to be different from that of the claimant, and for which another patent has been granted, will still be treated as a use under the contract, if it be held that the devices are really equivalent.'.

A difficulty often arises, however, in cases where the officers of the government use a patented device either in ignorance of the fact that the patent has been granted, or else in the belief that they are not using what is patented, or that they have a right to use it without regard to the fact of its being patented. As between individuals or corporations, relief in such cases could be sought on

the claim of a citizen deserves to be paid at all, it deserves to be paid as a matter of right, and that the existence of such right is purely a judicial question, to be determined by a court.

- United Stales v. Burns, 12 Wall. 246 (1871).

- E. g., Hubbell v. United States, 5 Ct. Cls. R. I (1869).

1 Pasqueau v. United States, 36 Ct. Cls. R. 509 (189I).

- Hollister v. Benedict MIg. Co., 113 U. S. 59 (1884).

- Pasquear v United States, Ct. of Clms. (1899), not reported. 
the ground of infringement merely, but infringement is a tort, and the United States, it is held, cannot be guilty of a tort and hence cannot be liable on any such ground. Unfortunately, many patentees have failed to realize that their legal right of recovery for the use of their patented devices was much more restricted as against the United States than as against private citizens, and hence have not sought to protect themselves by definite contracts; $;^{30}$ and, on the other hand, government officers seem to have often assumed that because the legal remedy. against the government was somewhat limited, therefore the possible consequence of the use of a patented invention was no concern of theirs and could be left to take care of itself.

In order to secure relief in such cases, patentees have invoked the doctrine of implied contracts, and also the constitutional provision that private property shall not be taken for public use without just compensation. In one of the first suits ${ }^{11}$ brought in the Court of Claims, after its reorganization in 1863 , where the warden of a United States penitentiary had bought certain machines, made without authority from the assignee of the patent, the claimant urged both of these points, but the petition was dismissed on demurrer. The court held that the warden, being merely a subordinate officer, had no. power to take property for the government's use or to bind it by contracts without either express authority of law or

10 The case of Kirk v. Uniled States, 163 U. S. 49 (1895), is an extreme illustration of the idea, prevalent among some patentees, that any claim ought to be valid. "If a patentee," said the court, "could under any circumstances sue to recover for the use of a patented article. made before letters were granted, . . . it cerlainly could not apply to a case where the patentee was not the inventor of thing patented; where the device had been in public use more than two years before the patent was applied for; and where the government, so far from agreeing to pay a royalty for it, had protested against any patent beirg issued for it. We know of no principle upon which a contract can be evoled from a distinct refusal of one party to recognize the rights of the other, and a formal protest against any such rights being granted to him."'

${ }^{21}$ Pitcher v. United States, x C. Cls. R. 7 (1864). 
the direction of some superior officer who had such authority, so that there had not been any taking of private property for public use within the meaning of the constitution, and further that the incapacity of the government to commit or authorize a tort was no reason for implying a contract from the acts of one who could not contract expressly. The case was held to be one of infringement pure and simple, where the regular statutory remedy against the individual infringer was available, though whether such remedy would be appropriate and ample in this particular case, the court did not feel called upon to decide.

Practically this case decided two points: first, that a recovery against the United States, in a suit on a patent, must be based on some other ground than that of infringement (a point substantially conceded in the petition), and second, that no liability can be imposed upon the United States by implication from the act of an agent who would have had no authority to bind the government by express agreement in regard to the particular matter.

The decision on this latter point seems to have been overlooked by Judge Davis, in the opinion in Talbert $v_{\text {a }}$ United States,", when he said: "Admiral Smith had not the power to commit the government to a contract for royalty, but an implied contract arose, as we have seen, from the user, and having taken advantage of the act of their agent, Admiral Smith, the chief of the Bureau of Yards and Docks, in applying the device, they must be held to the condition, agreed upon by him and Talbert, that the patentee should be compensated." In that particular case the suit was under a special jurisdictional act, authorizing compensation for the use of the invention, so that it was immaterial whether a contract could have been implied or not, and hence the statement just quoted must be regarded as obiter. Certainly it cannot be reconciled with the decision in Pitcher v. United States, which is itself manifestly founded on reason.

The argument that the government's use of a patented

1325 C. Cls. R. 142 (1890). 
device, whether by way of contract or not, should always be the subject of compensation as a taking of private property for public use, came up again after the jurisdiction of the Court of Claims had been somewhat amplified in 5887 , so as to cover-

"All claims founded upon the constitution of the United States or any law of Congress, except for pensions, or upon any regulation of an executive department, or upon any contract, express or implied, with the government of the United States, or for damages, liquidated or unliquidated, in cases not sounding in tort, in respect of which claims the party would be entitled to redress against the United States either in a court of law, equity, or admiralty if the United States were suable."13

Within a month after the act was passed, suit was brought on a patent, the petition setting up an infringement, and stating that "the basis of this suit is upon their [the claimants'] patent rights, which are founded upon the patent laws of the United States." These words were evidently used with the idea of setting up a claim founded upon a "law of Congress." In delivering the opinion of the Supreme Court," Mr. Justice Brewer cited Gibbons v. United States and Morgan v. United States (supra), to the effect that the act of $186_{3}$ had given the Court of Claims no jurisdiction over torts, and said:

"It is said that the constitution forbids the taking of private property for public uses without just compensation; that, therefore, every appropriation of private property by any official to the uses of the government, no matter however wrongfully made, creates a claim founded upon the constitution of the United States and within the letter of the grant in the act of 1887 of the jurisdiction to the Court of Claims. If that argument be good, it is equally good applied to every other provision of the constitution as well as to every law of Congress. This prohibition of the taking of private property for public use without compensation is no more sacred than

13 Act of Mar. 3, 1887 , generally known as the Tucker Act, 24 Stats. 505, Supp. R. S., Vol. 1, 559.

14 Schillinger v. United States, 155 U. S. 163, 168 (1894). 
that other constitutional provision that no person shall be deprived of life, liberty, or property without due process of law. Can it be that Congress intended that every wrongful arrest and detention of an individual, or seizure of his property by an officer of the government, should expose it to an action for damages in the Court of Claims? If any such breadth of jurisdiction was contemplated, language which had already been given a restrictive meaning would have been carefully avoided.

"It is true also that to jurisdiction over claims f- inded 'upon any.contract, expressed or implied, with the government of the United States,' is added jurisdiction over claims 'for damages, liquidated or unliquidated,' but this grant is limited by the provision 'in cases not sounding in tort.' This limitation, even if qualifying only the clause immediately preceding, and not extending to the entire grant of jurisdiction found in the section, is a clear endorsement of the frequent ruling of this court that cases sounding in tort are not cognizable in the Court of Claims.

"That this action is one sounding in tort is clear. It" is in form one to recover damages. The petition charges a .wrongful appropriation by the government, against the protest of the claimants, and prays to recover the damages done by such wrong. The successive allegations place the parties in continued antagonism to each other, and there is no statement tending to show a coming together of minds in respect to anything. It is plainly and solely an action for an infringement, and in this connection reference may be made to the statutory provision (Rev. Stats., Section 49r9) of an action on the case, as the legal remedy for the recovery of damages for the infringement of a patent. If it be said that a party may sometimes waive a tort and sue in assumpsit, as on an implied promise, it is technically a sufficient reply to say that these claimants have not done so. They have not counted on any promise, either express or implied.

"But we do not care to rest our decision upon the mere form of action. The transaction as stated in the petition, and as disclosed by the findings of the court, was a tort 
pure and simple. The case was, within the language of the statute, one 'sounding in tort.' It is in this respect essentially different from United States v. Palmer, 128 U. S. 262,269 ( 1888 ). That was an action to recover for the authorized use of a patent by the government. . . .

"Here the claimants never authorized the use of the patent right by the government; never consented to, but always protested against it, threatening to interfere by injunction or other proceedings to restrain such use. There was no act of Congress in terms directing, or even by implication suggesting, the use of the patent. No officer of the government directed its use, and the contract which was executed by Cook did not name or describe it. There was no recognition by the government or any of its officers of the fact that in the construction of the pavement there was any use of the patent, or that any appropriation was being made of claimant's property. The government proceeded as though it were acting only in the management of its own property and the exercise of its own rights, and without any trespass upon the rights of the claimants. There was no point in the whole transaction from its commencement to its close where the minds of the parties met or where there was anything in the semblance of an agreement. So not only does the petition count upon a tort, but also the findings show a tort. That is the essential fact underlying the transaction and upon which rests every pretence of a right to recover. There was no suggestion of a waiver of the tort or a pretence of any implied contract until after the decision of the Court of Claims that it had no jurisdiction over an action to recover for the tort."

Mr. Justice Harlan and Mr. Justice Shiras dissented from this conclusion on two grounds: first, "that when the government, by its agent, knowingly uses or permits to be used for its benefit a patented invention, it is liable to suit in the Court of Claims for the value of such use, and that its liability arises out of [a] contract based upon the constitutional requirement that private property shall not be taken for public use without just compensation;" and second, that "independent of mere contract, . . . 
the claim to have just compensation for such an appropriation of private property to public use is founded upon the constitution of the United States," and therefore within the terms of the act of 1887 .

In United States v. Berdan Firearms Co. ${ }^{15}$ decided but a few months after the Schillinger case, the government had again denied the existence of a contract, but .t was held that it must be implied, and even from what the findings failed to show as well as from what they showed. Mr. Justice Brewer, who had himself delivered the opinion in the Schillinger case, said:

"In the case at bar, according to the nineteenth finding, 'Berdan, as an officer of plaintiffs herein, assignees of his inventions during the period covered by this action, was in constant communication with the ordnance officers, requesting the use of his devices by the government; they knew him as an inventor, and knew his inventions as soon as they were patented;' and, by the twenty-third, 'the plaintiffs have desired the government should use their patented devices, and have also desired and requested compensation for such use.' So far, then, as the petitioner is concerned, the use of this invention was with its consent, in accordance with its wish, and with the thought of compensation therefor.

"While the findings are not so specific and emphatic as to the assent of the government to the terms of any contract, yet we think they are sufficient. There was certainly no denial of the patentee's rights to the invention; no assertion on the part of the government that the patent was wrongfully issued; no claim of a right to use the invention regardless of the patent; no disregard of all claims of the patentee, and no use, in spite of protest or remonstrance. Negatively, at least the findings are clear. The government used the invention with the consent and express permission of the owner, and it did not, while so using it, repudiate the title of such owner.

"The nineteenth finding, besides showing knowledge on the part of the officers of the government of Berdan's

15 156 U. S. $55^{2}$ (1894) 
invention, states, in a general way, that 'the attitude of the War Department towards inventors in ordnance has been one of neutrality; it has neither denied nor admitted the legal rights, if any there were, of inventors; in an endeavor to perfect the government arm that department has taken advantage of all kriowledge within its reach and of all inventions; it does not deny the claims of inventors, but has proceeded upon the policy that executive officers should not decide upon such claims against the government or upon conflicting claims, but that the claim should be presented without prejudice before some other tribunal than an executive department.

"The import of these findings is: That the officers of the government, charged specially with the duty of superintending the manufacture of muskets, regarded Berdan as the inventor of this extractor-ejector; that the difference between the spiral and flat spring was an immaterial lifference; that, therefore, they were using in the Springield musket Berdan's invention; that they used it with is permission as well as that of his assignee, the petiioner, and that they used it with the understanding that he government would pay for such use as for other prirate property which it might take, and this, although hey did not believe themselves to have the authority to gree upon the price."

The case of Russell v. United States" resembled the Jerdan case in some respects, but was held to involve an nfringement and not a contract. A contract existed letween the government and another patentee, the Kragorgensen Company, wherein the patentee guaranteed the overnment against all claims on account of patents, as egards both the patented and the unpatented portions if the gun, but shortly before that contract had been made he appellant had notified the chief of ordnance that cerain claims in his own patent were infringed in the contructon of the gun, and requested that "in considering he allowance to inventors . . . our claims for these

36 183 U. S. 516 (I90I). 
vital points of construction be regarded." The reply was as follows:

"The business arrangements with the Krag-Jörgensen Company for the manufacture of this arm have not yet been completed.

"On the one hand; that company may agree to.indemnify the United States on account of any patent rights granted by the United States which may affect the manufacture of the guns, in which case your recourse would be to communicate directly with the company.

"On the other hand, should the government.proceed to manufacture the arms without such arrangement, your course will be to bring a suit against the government in the Court of Claims after manufacture has progressed."

Other communications followed between the appellant and the ordnance office, in which the words "infringe" and "infringement" were repeatedly used, and in more than one of which the appellant was informed that the case "cannot be determined by the Ordnance Department."

The position taken by the chief of ordnance in this case was practically the same as in the Berdan case, viz., that he could not undertake to decide whether any part of the claimant's patented device had been used or not, and that if the claimant wished compensation he should sue in the Court of Claims. It does not appear that the chief of ordnance had asserted that the government had any right, as against Russell, to use that portion of the Krag gun mechanism which Russell said was covered by his patent, and the difference between the two cases was mainly in the way the parties had expressed themselves in their dealings with each other. In the Berdan case apparently no expressions had been used inconsistent with the idea of a contract, although of course the word "contract" had never itself been used, while in the Russell case the words "infringe" and "infringement" had been used repeatedly on both sides. Substantially, then, the Russell case seems to decide merely that if a patentee deliberately treats the case as one of infringement, he cannot be allowed afterwards to say that he did not mean 
infringement, but meant implied contract. It is to be observed that Shiras, White, and Peckham, JJ., dissented, and that Harlan, J., did not participate in the case. Had he done so, he would probably have dissented as he did in the Schillinger case, so that the decision may fairly be regarded as carried by a majority of one only.

In the recent case of United States v. Lynah, ${ }^{17}$ involving the flooding of land in the improvement of a river, $\mathbf{M r}$ Justice Brown (who had sided with the majority in both the Schillinger and the Russell cases) said, in a concurring opinion: "As we had occasion to remark in Dooley v. United States, 182 U. S. 222, 224, the first section of the Tucker act evidently contemplates four distinct classes of cases: (I) those founded upon the constitution or any law of Congress, with an exception of pension. cases; (2) cases founded upon a regulation of an Executive Department; (3) cases of contract, express or implied, with the government; (4) action for damages, liquidated or unliquidated, in cases not sounding in tort. The words 'not sounding in tort' are in terms referable only to the fourth class of cases." He also stated that in the Schillinger case the question of a claim under the constitution of the United States had only been considered in the dissenting opinion, and he added:

"I think it is going too far to hold that the words of the Tucker act, 'not sounding in tort,' must be referred back to the first class of cases, namely, "those founded upon the constitution,' and that they should be limited to actions for damages, liquidated or unliquidated, and, hence, the consent of the owner cuts no figure in this case. I freely admit that, if property were seized or taken by officers of the government without authority of law, or subsequent ratification, by taking possession or occupying property for public use, there could be no recovery, since neither the government nor any other principal is bound by the unauthorized acts of its agents. But in endeavoring to raise an implied contract to pay for an ordinary trespass to real estate, I think the opinion of the court misconceives the true source of our jurisdiction."

${ }^{17} 188$ U. S. $445^{\circ}$ (1903). 
It will be recalled that in the Schillinger case the opinion suggests the possibility that the limitation "in cases not sounding in tort" may be understood as "qualifying only the clause inmediately preceding" (the clause as to claims for damages, liquidated or unliquidated), "and not extending to the entire grant of jurisdiction found in the section." In view of that suggestion and of the recent statements of Mr. Justice Brown, it would seem probable that if a case arose in which the petition alleged neither implied contract. nor infringement, but simply a use or appropriation of the patented device, and a claim for compensation under the constitution of the United States for private property taken for public use, the jurisdiction might be sustained in accordance with Mr. Justice Harlan's second ground of dissent in the Schillinger case. As far as the cases actually decided go, however, it may be said that the Court of Claims has no jurisdiction in cases where the officers of the government use a particular device, asserting a right to do so even as against one who claims to be a patentee, except in cases where a contract between the patentees and the government is still in force in regard to the device in question, and also where the government asserts a free license, express or implied, from the patentee. The state courts have jurisdiction in suits upon patents only where the recovery sought is limited to an agreed compensation for the use of the device, in the form of a royalty or license fee, and the Court of Claims has held that its jurisdiction is that of the state courts, amplified by jurisdiction in cases of alleged implied contract also."

In view of the limited jurisdiction of the Court of Claims, some patentees have undertaken to proceed personally against the government officers who have been concerned in using the alleged infringing devices; but it has been held that an injunction will not lie to restrain the construction or operation of public works; that public officers, who make no profit from the use of a patented device on public works, cannot be required

13 Gill v. Urited States, 25 C. Cls. R. 415 (1890). 
to account for profits, and further, that where no damages have been proved, except the gain to the United States from the use of the device, no damages can be recovered from the government's officer. ${ }^{10}$ This method of securing compensation is therefore unfruitful.

An implied contract is founded upon a presumed agreement, ${ }^{20}$ but such a presumption must always be based upon evidence showing that the parties, if reasonable men, must have agreed. Hence no contract can be implied from the mere use of a patented device by government officers through ignorance, carelessness, or mistake, or without proper authority. ${ }^{21}$ So, too, where the government uses a mechanical device of any kind as the invention of a certain person, and under a contract with him, no contract can be implied with a third party who asserts that the device used is really covered by his patent. Such a claim, if valid at all, is for an infringement, and is not within the jurisdiction of the Court of Claims." The same doctrine of course applies where the government declines the offer of a particular device, and subsequently its officers adapt other devices to attain the desired results.23

Where an officer, with authority to control contracts and prevent his subordinates from incurring liability, declines to contract with a patentee, stating that his practice is to buy from manufacturers only, with whom the patentee can make his own arrangements, no contract can be implied from a subsequent use of the patented device by subordinate officers. ${ }^{24}$ And where the

\footnotetext{
10 Belkrap v. Schild, 16I U. S. 10 (1895). Harian and Field, JJ., dissented on the ground that there was an adequate remedy against the government on an implied contract. James v. Campbell, sof U.S. 356 (I88I), and Hollister v. Bercdict Mfg. Co., II3 U.S. 59 (1884), also suits against public officers, had been decided adversely to the patentees on the merits.

${ }^{20}$ Simpson v. United States, 31 C. Cls. R. 217.245 (1896).

21 Foreliand v. United States, 23 C. Cls. R. 477 (1888).

${ }^{22}$ Fletcher v. United States, I I C. Cls. R. 748 (1875); Coston v. United States, 33 id. 438 (1898); Henry v. Unitcd States, 38 id. - (1903).

2 IWood v. United States, 36 C. Cls. R. 418 (1900).

24 Sprague v. Uniled States, 37 C. Cls. R. 448 (1902).
} 
government has a license to use a certain mechanism, a part of which is patented, and subsequently a patent is issued for another part, which the government claims the right to use under the license, without additional compensation, no contract for any further compensation can be implied.

Where, on the other hand, the evidence shows an offer of an invention already patented, and an acceptance of it as such, and a use under proper authority, the court will take jurisdiction of the case as one where a contract to pay a reasonable royalty must be implied. "When a vendible article, such as ordinarily is the subject of bargain and sale, is offered by a producer to a consumer, though with no price specified, and is accepted and used by the latter, it is not to be supposed on the one hand, that the offer was intended as a gift inter vincs, nor implied on the other hand that the taking was with a tortious intent."28 The fact that the parties did not agree upon a price is immaterial, it being presumed that the government expected to pay, and the patentee to receive, a reasonable price. ${ }^{n}$

Even in cases where a contract with the original patentee might be implied, an assignment of the patent would not, apparently, transfer to the assignee any right of suit against the United States: Sections 3477 and 3737 of the Revised Statutes show a clear intention to prevent the transfer or assignment of any liability of the government, however arising, until that liability is established by judgment or otherwise, and a warrant has been issued for its payment. An implied contract can in no sense be transferred until it has been established by a judgment or some departmental action, and a warrant has issued for the payment of what is due upon it, and even then only the claim for payment upon the implied contract can be assigned, not the contract itself. For instance,

25 Dashiell v. United States, 36 C. Cls. R. 115 (1901).

4 Mlckever v. United States, 14 C. Cls. R. 396 (1878).

$n$ United States v. Palmer, 128 U. S. 262 (1888); United States v. Berdan Firearms Co., 156 U. S. 552 (1894). 
in Pasqueau v. United States, ${ }^{28}$ a judgment was recovered upon an implied contract, and in a later suit by the same claimant another judgment was recovered upon the same implied contract. After judgment and the issuance of a warrant, Pasqueau could have transferred his first claim, but if he had assigned his patent his assignee could not have brought suit for the second claim, as such suit would have been based upon the assignment of an implied contract with the government, in violation of the statute.

Turning from the question of jurisdiction to other matters, several interesting points may be noted.

As the proceeding cannot be for an infringement - (except by a special jurisdictional act), Section 4920 of the Revised Statutes does not apply, so that the government files no notice of special matter, and only discloses its defense by the character of the testimony it takes.

In the case of an express contract which had been assigned (prior to the enactment of R. S., section 3737, forbidding the transfer of public contracts) the disloyalty of the patentee was held not to affect the government's liability to the assignee. ${ }^{20}$ On the other hand, the government is entitled to all the benefits of an express contract, and where the patentee is in the government's employ his leaving that employ does not terminate the contract, even though made for a nominal consideration. ${ }^{*}$

A number of cases have arisen where inventions have been made and patented by persons in the employ of the government. In Talbert v. United States, ${ }^{31}$ the device had been fully invented before the claimant entered the government's service, but not patented until afterwards, though the patent had been applied for before the government ordered the device (a form of marine railway) to be constructed. The chief of the Bureau of Yards and Docks had promised compensation, but the Secretary of the Navy had refused it, erroneously thinking that no

226 C. Cls. R. 509 (1891).

2) United States v. Buriss, 12 Wall. 246 ( 1871 ).

${ }^{30}$ McAleer v. United States, 150 U. S. 424 (1893).

${ }_{23}{ }_{25}$ C. Cls. R. 14 I (1890). 
compensation could be paid to an employe in such a case. Suit was brought under a special act, but the chief of the bureau's lack of authority seems to be all that would have prevented a recovery. upon the contract under the court's regular jurisdiction.

Where an inventor, being in the government's service, makes experiments at the government's expense, is consulted about the adoption of the device, and recommends it, saying that under the circumstances he will make no charge, this constitutes an agreement for a free license, valid even as against an assignee of the patent." Moreover, where nothing whatever is said as to a future claim for compensation, and the original drawings had been made by the patentee in his own time, without cost to the government, but the device was first embodied in the form of an operative machine at the government's cost, and the patentee had seen it adopted and used for a considerable time without making any claim, these circumstances have been held to imply a free license to the government.s3 It was contended, indeed, that the fact that the invention existed on paper, in the drawings, before the government undertook any expense in the matter, was evidence that no contract could have been intended, but Mr. Justice Brown said:

"An attempt is made to differentiate the case under consideration from those cited ${ }^{34}$ in the fact, stated in the

"Solomons v. United States, 137 U. S. 342 (1890). This was followed in Davis v. United States, 23 C. Cls. R. $3_{29}$ (1888), where the patentee had been ordered to make the experiments, and get up the desired device, as a part of his regular work, and the government paid the cost of taking out the patent, nothing being said about compensation.

23 Gill v. United States, 160 U. S. 426 (1895). This case was followed in Eager v. United States, 35 C. Cls. R. 55 (1900). The judgment in the Eager cace was afterwards set aside and a new trial grar.ted, but the court ultimately reached the same conclusion as before. In Horley v. United States, decided Dec. 21, 1903, it was held that long-continued failure to demand compensation sufficed to prevent a contract from being implied, the patentee being in government employ, and his superiors believing that on that account a free license was granted.

"These were MICClurg v. Kingsland, I How. 202 (1843); Solomons v..United Siates, 137 U.S. 342 (1890); Lane E Bodlcy Co. v. Lock:, 150 id. 193 (1893); MfcAlecr v. United States, id. 424 (1893); Keyes v. Eureka Mining Co., 158 id. 250 (1894). 
third finding, that the invention in this case, until it was reduced to paper, in the form of an intelligible drawing, was made out of the hours of labor at the arsenal, and during the time which properly belonged to the patentee, and that, by finding four, 'the claimant did not use any property of the defendants or the services of any of the employes of the defendants in making, or developing, or perfecting the inventions themselves.' This, however, must be taken in connection with the further finding that 'the cost of preparing patterns for the iron and steel castings, and of preparing working drawings, and of constructing machines was borne exclusively by the government,' and that in each case, one or more machines or articles of manufacture embodying the invention, had been constructed and was in operation or use in the arsenal with the claimant's knowledge and consent before he filed an application for a patent. The inference to be deduced from the findings is, in substance, that, while the claimant used neither the property of the government, nor the services of its employes in conceiving, developing or perfecting the inventions themselves, the cost of preparing the patterns and working drawings of the machines, as well as the cost of constructing the machines themselves that were made in putting the inventions into practical use, was borne by the government, the work being also done under the immediate supervision of the claimant.

"There is an assumption by the claimant in this connection that, if he did not make use of the time or property of the government in conceiving and developing his ideas, the fact is an important one as distinguishing this case from those above cited. In view of the finding that he did not make use of the property and labor of the government in preparing patterns and working drawings and constructing his working machines, the distinction is a very narrow one-too narrow, we think, to create a difference in principle, or to prevent the application of the rule announced in those cases.

"In every case, the idea conceived is the invention. Sometimes, as in the case of McClurg v. Kingshund, a 
series of experiments is necessary to develop and perfect the invention. At other times, as in the case under consideration, and apparently in the Solomons case, the invention may be reduced to paper in the form of an intelligible drawing, when nothing more is necessary than the preparing of patterns and working drawings, and the embodiment of the original idea in a machine constructed accordingly. Now, whether the property of the government and the services of its employes be used in the experiments necessary to develop the invention, or in the preparation of patterns and working drawings, and the construction of the completed machines, is of no importance. We do not care, in this connection, to dwell upon the niceties of the several definitions of the word 'develop' as applied to an invention. The material fact is that, in both this and the Solomons case, the patentee made use of the labor and property of the government in putting his invention into the form of an operative machine, and whether such employment was in the preliminary stage of elaborating and experimenting upon the original idea, putting that idea into definite shape by patterns or working drawings, or finally embodying it in a completed machine, is of no consequence. In neither case did the patentee risk anything but the loss of his personal exertions in conceiving the invention. In both cases, there was a question whether machines made after his idea would be successful or not, and if such machines had proven to be impracticable the loss would have fallen upon the government.

"In this connection, too, it should be borne in mind that the fact, upon which so much stress has been laid by both sides, that the patentee made use of the property and labor of the government in putting his conceptions into practical shape, is important only as furnishing an item of evidence tending to show that the patentee consented to and encouraged the government in making use of his devices. The ultimate fact to be proved is the estoppel, arising from the consent given by the patentee to the use of his inventions by the government, without demand for compensation. The most conclusive evi- 
dence of such consent is an express agreement or license, such as appeared in the McAleer case; but it may also be shown by parol testimony, or by conduct on the part of the patentee proving acquiescence on his part in the use of his invention. The fact that he made use of the time and tools of his employer, put at his service for the purpose, raises either an inference that the work was done for the benefit of such employer, or an implication of bad faith on the patentee's part in claiming the fruits of labor which technically he had no right to enlist in his service. .

"The acquiescence of the claimant in this case in the use of his invention by the government is fully shown by the fact that he was in its employ; that the adoption of his inventions by the commanding officer was procured at his suggestion; that the patterns and working drawings were prepared at the cost of the government; that the machines embodying his inventions were also built at the expense of the government; that he never brought his inventions before any agent of the government as the subject of purchase and sale; that he raised no objection to the use of his inventions by the government; and that the commanding officer never undertook to incur a legal or pecuniary obligation on the part of the government for the use of the inventions or the right to manufacture thereunder. It further appeared that from time to time his wages were advanced from four to six dollars a day, and while it was never stipulated by the commanding officer, or understood by the claimant, that the advance of wages was a consideration for the use of the inventions, the practical ability of the claimant as an inventor, and the value of his inventions to the government, did operate on the minds of the officers in estimating the claimant's services and ordering his advancement.

"Clearly, a patentee has no right, either in law or morals, to persuade or encourage officers of the government to adopt his inventions, and look on while they are being made use of year after year without objection or claim for compensation, and then to set up a large demand, upon the ground that the government had impliedly promised to pay for their use. A patentee is 
bound to deal fairly with the government, and if he has a claim against it, to make such claim known openly and frankly, and not endeavor silently to raise up a demand in his favor by entrapping its officers to make use of his inventions. While no criticism is made of the claimant, who was a simple mechanic, and, as found by the Court of Claims, 'a faithful, intelligent and capable employe, whose services were of great value to the government, and whose conduct was 'fair, honest and irreproachable,' and while the government appears to have profited largely by his inventive skill, we are of opinion, for the reasons above stated, that the appeal in his behalf should be addressed to the generosity of the legislative, rather than to the justice of the judicial department."

Where a government officer not merely uses the service of other officers and the government's machinery to perfect his inventions, but also is influential in procuring its adoption, he can recover no compensation for its use. In such a case, Nott, C. J., said:

"In this court public officers have always been regarded as guardians of the public welfare, and the government as a ward which is always under the protection of the court. . . The invention was brought to the attention of the ordnance officers by virtue of Colonel Kelton's official position, and they consulted and deferred to him in regard to the number which should be manufactured at the outset. He could not, at one and the same time, be the adjutant-general of the military department determining the number of the sight covers which should be issued for use, and the inventor claiming a royalty for the device."

When the United States is sued for the use of a patent, on a claim of implied contract, every defense is open to it which is open to the defendant in an-ordinary infringement suit, because no contract to pay royalty on a device covered by an invalid patent, or by any invalid claims of a patent, can be implied. Such invalidity would be a failure of consideration, fatal to the contract which the

"Kelton v. United Stales, $3_{2}$ C. Cls. R. $3^{14}$ (1897). 
claimant seeks to establish. ${ }^{*}$ Moreover, the fact that a patent is issued in the name of the United States, and that a fee has been required to be paid for such issue, does not estop the government from defending on the ground of the invalidity of the patent or claims relied on. When the Secretary of the Interior issues a patent in the name of the United States, his act is not of the same character as when he contracts for work to be done or supplies to be furnished. The United States, as represented by him, does not act in the same capacity in the two cases. In the latter it contracts for itself, in its individual capacity, so to speak; but in the former it contracts in a fiduciary or representative capacity, in behalf of the whole body of people in the country. A patent for an invention constitutes a contract, but it is a contract between the inventor and the public, in which the government acts as "the steward of public rights," the "representative of the community."

"It should always be remembered that in the grant of a patent privilege, as now understood, a contract takes place between the public and the patentee, to be supported upon the ground of mutual considerations, in all its essential features, each having rights and interests involved in its stipulations.

"A patent should be construed as what it really is in substance, namely, a contract or bargain between the patentee and the public, upon those points which involve the rights and interests of either party."

"The concession of the patent privilege by the state is an act having a threefold character. As a reward bestowed upon the inventor for his past inventions; it is an act of justice. As an inducement to future efforts, it is an act of sound public policy. As a grant of temporary protertion in the exclusive use of a particular invention, on condition of its immediate publication and eventual surrender to the people, it is an act of compromise between the inventor and the public, wherein each concedes some-

\footnotetext{
" Gill v. United States, 25 C. Cls. R. 425 (1890).

"Coryton on Patents, 20. "M Curtis on Patents, zxiii, xurr.
} 
thing to the other in return for that which is conceded to itself. In this latter character it is a true contract, to the stipulations in which each party is bound with the same strictness as in any other contract, and which is to be interpreted in the same manner as other. legal obligations."

It was this feature of patents for inventions which distinguished them from other monopolies, under which the public received nothing, and caused patents to be expressly excepted from the operation of the statute 21 James I, ch. 3, abolishing monopolies.

In this contract between the inventor and the public, a contract which the government makes as agent only, not as principal, the consideration must be something which moves from the inventor to the public, the principal, and not to its agent. The trifling office fees paid by the patentee are merely charged to cover necessary expenses, and cannot constitute the consideration for the grant. What that consideration really is is indicated by the words of the constitution, "To promote the progress of science and useful arts, by securing for limited times to authors and inventors the right to their respective writings and discoveries." The consideration for a patent is the promotion of the progress of science and useful arts, the benefit to the community by the increase of its knowledge and power, effected by the disclosure of the invention. An inventor who, by the description contained in his patent, discloses to the community a useful art, machine, manufacture, or composition of matter, of which it had no knowledge before, adds to the capabilities of the community, and, in addition to whatever gain may come to himself, contributes, in a very direct sense, to its wealth. This contribution of his is the consideration for his patent, and to suppose that the trifling office fees constitute any part of the consideration is to misunderstand the whole object of our patent system. Patents are not granted in order to keep up a patent office, but in order to secure to the public the disclosure of inven-

- Robinson on Patents, 40. 
tions, in consideration of a limited right of monopoly to the inventor.

As was said, some years ago, by an English writer:

"Letters patent for inventions are grants under the great seal, whereby, in consideration of the improvement effected by such inventions in trade, the exclusive enjoyment of such improved trade for a limited period is assured to the parties first communicating the inventions to. the public."

The same thought is seen in the statement of Robinson, quoted above, where he refers to the "immediate publication" of the invention, and its "eventual surrender to the people," as the condition upon which the inventor receives a temporary right of exclusive use. "Condition," as there used, means consideration. The immediate publication and eventual surrender are the consideration for the grant to the inventor; and hence, just as he who, under a contract, pays a money consideration, is under an obligation to pay in lawful money, not in spurious or counterfeit coin, so the inventor, in the payment of his consideration to the public, has an obligation, which is two-fold: "(1) The result of his inventive skill must be of such a nature that a patent may lawfully be granted to protect it; (2) the invention itself must be fully communicated to the public."'

All this is so axiomatic, as well as so fundamental, that the courts have scarcely ever been called upon to consider it, but it lies at the foundation of the right of a court to inquire into the validity of a patent in any case. If the so-called invention which the patentee publishes, and which is eventually to be surrendered to the public, has already been published, and is already surrendered, or about to be surrendered, to the public, by some one else; or if, though the first to publish, the alleged inventor is not really the first inventor, and hence not entitled to publish and eventually surrender the invention; then there is clearly a failure of consideration, and the patent must be declared void, either in whole or in part as the

- Coryton on Patents, 1.

a. Robinson on Patents, 42. 
case may be. Every judgment of a court, invalidating a patent or any part of it, is simply a judgment that the consideration for which the patent is granted has failed in whole or in part.

When any one of the public, being sued on a patent, defends on the ground of its invalidity, he merely asserts, as (unless he has himself held and assigned the patent) he has a perfect right to do, that in the contract between. the inventor and the public there was no real consideration, that the public, including himself, derived no benefit from it. When the United States is sued on a patent, it is not sued as the sovereign, or in its capacity as steward of public rights, the capacity in which it has authorized the Secretary of the Interior to issue patents in certain cases, but merely as a part of that public with whom the patentee has contracted: and in such a suit the United States government has clearly the same right to set up lack of invention or lack of novelty (i. e., failure of the consideration for which the patent was granted) that any other part of the public has. The grant of a patent has never been held to involve any kind of guaranty of its validity, and when the United States consents to be sued as an individual user of a patent might be, it does not assume the position of a guarantor of a patent any more than in the case of a suit against an individual.

In Morse Arms Mfg. Co. v. United States, ${ }^{2}$ it was contended, on a motion to strike out a special plea, that the government could not attack the validity of a patent which it had itself granted. The Court of Claims reviewed a number of cases in regard to the estoppel of persons using patents under contract, and said:

"Applying these principles to this case, the contract set forth in the complaint does not preclude the defendants from setting up that Morse was not the first inventor of the alleged improvements.

"If the special contract is relied on, the pleadings show

06 C. Cls. R. 296 (1880). In an earlier case, Hubbell v. United States, 5 C. Cls. R. I (1869), one of the patents in suit had been held to be invalid, but that suit was brought under a special act, recovery being conditional upon validity. 
that the alleged prior contract, if it ever existed, had neither term nor rate. Under such pleadings we cannot shut out the defendants from proving that any use of the alleged improvements which may be proved subsequent to the special licenses was not made under a special contract, or that Morse was not their real inventor.

"On the other hand, if the claimant relies on an implied contract, it is an elementary principle, settled by long practice, that a mere use of a patented improvement does not imply a recognition of the validity of the patent. The validity of the patent, its novelty, and the truth of its invention by the patentee, are the first elements in testing the value of its use.

"A plea that the alleged patent is no patent, that it is void for want of novelty, that the alleged inventor of the improvement was not the real inventor, does not take away the jurisdiction when once acquired. Taken by itself, it goes to the question of damages, showing either an entire failure of consideration, or, as in McKeever's case, a partial failure.

"It is therefore the duty of the court to retain such cases, even if it involves determining the validity of a patent."

When the case came before the court on the merits, some years later, ${ }^{\text {s }}$ the court so construed Morse's patent as to distinguish his device from that of the government, so that the validity of the patent was not passed upon, but nothing was done inconsistent with the first decision.

In 1885 , in Hubbell v. United States, "the point of nonpatentability was raised in the trial of the case, and was one of the alternative grounds upon which the decision rested. Davis, J., said:

"Under our construction of the patent in issue, the government cartridges do not infringe the claimant's; but if we are in error as to this, still the claimant cannot recover, as the essential characteristics of his invention now found in the government cartridge were developed by officers of the army in $186_{4}$-that is, if the relative

a Morse Arms Mfg. Co. v. Uniled States, 27 C. Cls. R. $3^{6} 3$ (1892).

420 C. Cls. R. 354 ( 1885 ). 
position of the vents and the wall of the fulminate chamber . . . is not material, still the claimant cannot recover, as the other characteristics of his invention found in the cartridge now used by the defendants were introduced by them prior to the issue of the patent or the filing of the application for it, and even prior to the application of $1865 . "$

The judgment was affirmed ${ }^{15}$ for the first of the reasons given by Judge Davis, and hence the Supreme Court did not pass upon the second point; but there are other cases, differing from these only in form, in which that court has sustained the defendant's right to attack the validity of the patent. A suit against an officer of the United States on account of the use of a patented device in government work under his charge, a matter in which he has no personal interest whatever, is really, in all but the name, a suit against the government, practically just as much so as a suit against a collector of customs or of internal revenue for taxes erroneously collected, for it is inconceivable that the government would not refund to its officer the amount of any judgment so recovered for the use of a patented device. Yet in Fames v. Campbell't and Hollister v. Benedict Manufastn:ring Co. ${ }^{17}$ the Supreme Court did not hesitate to hold a patent, or certain of its claims, to be invalid, where such a conclusion was warranted by the evidence. In fact, in the former case the court doubted very much whether the action could be sustained at all, "because it is substantially a suit against the United States," and should therefore have been brought in the Court of Claims: and in the latter case the court said that if an action could have been brought in the Court of Claims, a question which it did not decide, "all questions in relation to the validity of the patent" would have been involved.

It is therefore perfectly clear from these authorities that in any suit against the United States on a patent, the defendant may attack the validity of the patent

as Hubbell v. United States, 179 U. S. 77 (1900).

n 104 U. S. 356 (1881).

"II3 U. S. 59 (1884). 


\section{USE OP PATENTED INVENTYigis:}

as freely as might be done in a suit against an individual or a corporation.

In the case of an express contract, the Court of Claims has recently held that the United States is estopped from setting up the invalidity of the patent, as a failure of consideration, even though it was provided " that in case it should at any time be judicially decided that the party of the first part is not legally entitled, under the letters patent aforesaid, to own and control the exclusive right to the use and employment of said process and the decrementally hardened armor plates produced thereunder, as set forth in the letters patent aforesaid, then the payment of royalty under the terms of this agreement shall cease, and all sums of money due the party of the first part . . . as royalty . . . shall become the property of the party of the second part." This decision was strongly dissented from by one of the judges, and it is understood that an appeal will be taken. It is hard to see why the words "judicially decided" should not include a decision in a suit brought against the United States by the contractor, especially as the invention was one that would only be used for battleships, so that no. litigation would be likely to arise over the patent except in connection with a use by the United States. It follows from this decision that if the government had contracted with another party for armor plates made by a process which the Harvey Steel Company held to be really covered by its patent, the defense of invalidity of the patent could only be set up in a suit against such third party for the manufacture, not in a suit against the United States for the use. The reason for such a distinction is hard to understand.

Where the petition is dismissed because the device actually used was not covered by the patent sued on, and another suit is brought by the same party, based.upon a continuation of the same alleged use of the patented device, the defence of res judicata will be upheld, even though not specially pleaded, and even though due notice of an appeal

4 Harvey Steel Co. v. United States, $3^{8}$ C. Cls. R. - (2903). 


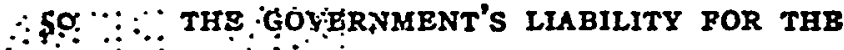

from the first judgment has been given, but the appeal not yet perfected."

In the case of a manufacture and use by the United States, the cause of action is held to accrue, and the statute of limitations to run, when the invention is first embodied in a manufactured article by the government's officers. ${ }^{\text {so }}$ Congress has, however, sometimes seen fit to remove the bar of the statute by special act, and even, in one instance, to grant to an applicant for a patent, a right of suit as if a patent had been granted, provided that the claimant should prove that the patent ought to have been granted. ${ }^{31}$

As the government does not manufacture articles for sale, the mere right to manufacture would be valueless to it, and hence the contract implied is a contract for the use of a patented device, and the claimant must prove the number of articles used, in order to recover damages.

Issuance for use is use, ${ }^{53}$ and the government cannot defend on the ground that the use was experimental, ${ }^{\text {sh }}$ or that the device used was of no utility, ${ }^{35}$ except, presumably, as to the rate of royalty. The government must pay for the use of an invention at the same rate at which such inventions are usually paid for by ordinary manufacturers," but as the government does not make profits, in the ordinary sense, out of the use of a patented device, the damages, where there is no established rate of royalty, must be estimated by the rule laid down in The Suffolk Co. v. Hayden," viz., on the basis of "the utility and advantage of the invention over the old modes or devices that had been used for working out similar results."ss The question is, what was the device worth in the market

- Hubbcll v. United States, 17 I U. S. 203 (1898).

. 10 Butler v. United Statés, 23 C. Cls- R. 335 (1888); Hartman v. United States, 35 C. Cls. R. 106 (1899).

4 Act of March 2, 1901, 3 I Stats.1788.

"Palner v. Uniled States, 19 C. Cls. R. 770 (1884).

* Palmer v. United States, 20 C. Cls. R. 432 (1885).

"Ibid.

u Palmer v. United States, 19 C. Cls. R. 770 (1884); 20 id. 432 (1885).

in Ialbert v. Uritcd States, 25 C. Cls. R. 142 (1889).

$" 3$ Wall. 315 (1865).

w Dahlgren v. United States, 16 C. Cls. R. 30 (1880). 
when taken? And if no market price can be shown, the court will adopt a price once agreed to by the parties, with such modification as the circumstances may make reasonable, $^{52}$ or, if no price was ever agreed upon, then the court will estimate the damages from such elements as the cost of manufacture, the ordinary percentage of royalty for similar articles, the judgment of persons familiar with sales or licenses in the case of similar articles, licenses to other parties by the patentee, etc. ${ }^{80}$ Nominal damages cannot be recovered in the Court of Claims."s

The rules of the Supreme Court relating to appeals from the Court of Claims make no special provision for suits on patents, and hence, in the matter of evidence, the parties are limited, on appeal, to "a finding by the Court of Claims of the facts in the case, established by the evidence, in the nature of a special verdict, but not the evidence establishing them," though all exhibits may, of course, be sent up with the record. Under this rule even the expert testimony which has been before the court below cannot be considered by the Supreme Court, except in so far as it may have been possible to incorporate it in the findings, and the rule has been held to apply even to an infringement suit, brought under a special act." The proceedings in the Patent Office, as shown by the filewrapper and contents, should, however, be embodied in the findings if properly requested, being just as relevant in a suit against the United States as in a proceeding against any other party. An inspection of the record in Hubbell v. United States ss shows that a finding of the facts shown by the file-wrapper and contents was refused by the Court of Claims, on the ground that they were not such facts as the court was required to find under the rule above quoted, whereupon a finding was made setting forth the statement which the court had been requested

\footnotetext{
4asqueau v. United States, 26 C. Cls. R. 509 (18gr).

${ }^{20}$ McKeever v. Untitcd States, 14 C. Cls. R. 396 (1878).

"Grant v. United States, 7 Wall. 331 (1868):

"Hubbell v. United States, 6 C. Cls. R. 53 (1870).

a 179 U. S. 77 ( 1900$)$, an entirely different case from the one cited in the preceding note.
} 
to find, and the refusal. The Supreme Court did not refer to this peculiar state of the record, but decided the point in the most unmistakable manner by devoting the opinion almost wholly to a discussion of the proceedings in the Patent Office, as shown by the file-wrapper and contents.

It is perfectly evident that neither the statutes which govern the Court of. Claims, nor the rules as to appeals from that court, have been drawn with any reference to the peculiar nature of suits on patents. As the issues in regard to the scope and validity of the patent are precisely the same where the government is charged with having used a patented device under an implied contract, as in an ordinary infringement suit, there is no reason-whatever for excluding any evidence from the consideration of the appellate court in the former class of cases, which would not be excluded in the latter class. There can hardly be a doubt that the exclusion of all expert testimony was due to a mere accident, the fact that when the rules were drawn the jurisdiction of the Court of Claims in patent cases was not taken into account. It is to be hoped that the rule will some day be amended, especially in view of the evident tendency to construe the scope of that jurisdiction rather broadly, and of the probable increase in the number of such patent suits. Certainly the parties to a suit in the Court of Claims are entitled to as full a consideration of every feature of their case in the appellate court as are the parties to any other judicial proceeding.

As to the statutes regulating the jurisdiction of the Court of Claims, if they cannot be legitimately construed so as to give a patentee the same rights in the case of an infringement by the government that he would have as against a private infringer, then the spectacle is presented of a constitutional right, the existence of which the Supreme Court has repeatedly recognized, but which cannot be asserted in any court, unless Congress can be persuaded to grant jurisdiction in any particular case. Such a state of affairs does not seem in accord with modern views as to the rights of the citizen. Just why the courts should 
be open to a patentee as a matter of right when an individual or corporation is the infringer, and not when the United States does the same thing, is not easy to see, at least from the patentee's point of view. The recognition of an enforceable right in all such cases would remove all. excuse for a resort to special legislation in favor of particular patentees, a practice which cannot be too severely condemned. No citizen can have any right to a judicial determination of his claim for the use of his patented device, except just such rights as are possessed by all other citizens in similar cases.

Charles C. Binney. 